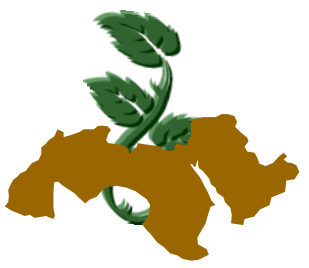

Arab Univ.

J. Agric. Sci., Ain Shams Univ., Cairo, 23(2), 537-547, 2015

\title{
QUALITY CHARACTERISTICS OF SPONGE CAKE AND BISCUIT PREPARED USING COMPOSITE FLOUR
}

\author{
Rizk1, I.R.S., Hemat, E. Elsheshetawy ${ }^{1}$, S.H. Bedeir², M.G.E. Gadallah¹ \\ and A.M. Abou-Elazm ${ }^{1}$ \\ 1- Food Sci. Dept., Fac. of Agric., Ain Shams University, Cairo, Egypt \\ 2- Food Science and Technology Institute, Agriculture Research Center, Giza, Egypt \\ Corresponding Author: Hemat, E. Elsheshetawy, Department of Food Science, Faculty of Ag- \\ riculture, Ain Shams University, Cairo, Egypt.
}

Keywords: Wheat flour, Chickpea, sorghum, Sponge cake, Biscuit, Quality properties

\section{ABSTRACT}

This study was carried out to investigate the effect of partial substitution (10 and $15 \%$ ) of wheat flour by sorghum or chickpea flour on quality parameters of sponge cake and biscuit. Chickpea flour contained the highest percentage of protein, lipids, ash and crude fiber. Water absorption was increased by replacement of wheat flour with sorghum or chickpea flour. From the obtained data, it could be seen that the deleterious effect of adding sorghum flour to wheat flour on the rheological properties was more pronounced than that happened when chickpea flour was added. Cake prepared with sorghum flour had less pronounced improvements in its chemical composition rather than those of chickpea. With regard to volume and specific volume, cake prepared with $10 \%$ chickpea flour with or without cake improver recorded the highest values. Cake prepared by chickpea flour had no any unfavorable sensory change especially for the cake produced by cake improver. Crude protein, lipids, ash and crude fiber contents were increased progressively in all biscuit samples with increasing of either the sorghum or chickpea flour levels. Also, there were no significant differences $(P>0.05)$ between the thickness and spread ratio of control biscuit compared to that of sorghum or chickpea- wheat composite flour. It is worth mentioning that the substitution of wheat flour with chickpea flour gave biscuit more sensory acceptable.

(Received 4 May, 2015)

(Accepted 24 May, 2015)

\section{INTRODUCTION}

Wheat (Triticum aestivum) is the most important crop for baking due to its absolute baking performance in comparison to all other cereals (Dewettinck et al 2008). Soft wheat flour has been used for a wide range of commercial baked products. Soft wheat flour is usually considered as good quality flour for soft wheat products such as cookies and cakes with a good quality property (Finney, 1989).

Sorghum is one of the cereals that constitute a major source of protein, calories and minerals for millions of people in Africa and Asia. World annual sorghum production is over 60 million tones, of which Africa produces about 20 million tones and Egypt produces 749000 tons (FAO, 2013). This cereal is mainly considered as subsistence crop because of its unique tolerance to drought and adaptain to dry tropical and subtropical ecosystem throughout the world (Murty and Renard, 2001). It, for human consumption, is generally utilized in the form of roti, snacks (puffed grain), porridges and noodles. Hulse et al $\mathbf{1 9 8 0}$ \& Chavan and Kadam, 1993, indicated the possibility of incorporating sorghum in wheat flour at various levels for producing bread, biscuit and other snacks.

Legume protein can be successfully used in baked products, to obtain a protein- enriched product with improved amino acid balance, the potential use of legumes as protein - enriching agents of baked products, mainly in the form of protein flours, has been reported by several authors (Hernandez and Sotelo, 1984, Hegazy and Faheid 2006, Demir et al 2009, Saleh et al 2012 \& Yadav et al 2012). Supplementation of wheat 
flour with chickpea would significantly enhance the protein quality of the product. (Hernandez and Sotelo, 1984).

Cake is a confectionary favorite product for Egyptian people and it used in their breakfast or at tea time. It's either homemade or prepared on commercial scale. On the other hand, biscuits can be used successfully as a vehicle for nutrient fortification in school feeding programs (Barakat 2003).

Biscuits are ready to eat, cheep and convenient food products that are consumed among all age groups in many countries (Hussein et al 2006 and Iwegbue, 2012). Biscuit have been reported to be rich in fat and carbohydrate; hence they can be referred to as energy giving food, as well as good sources of protein and minerals (Kure et al 1998). The main ingredient generally used for biscuit production is wheat flour with other ingredients such as margarine (Shortening), sweeteners (sugar), leavening agents, eggs, milk, salt and flavors (Hui, 1992 and Ghattas et al 2008).

Therefore, this work was aimed to study the effect of the partial replacement of wheat flour by sorghum or chickpea flour (10 and 15\%) on their proximate chemical composition as well as physical properties of the resulted dough. Baking characteristics of sponge cake and biscuit prepared from the different suggested replaced flours were also evaluated chemically, physically and organoleptically.

\section{MATERIALS AND METHODS}

\section{Materials}

Wheat flour (72\% extraction) was obtained from $6^{\text {th }}$ October for milling and marketing Co., $6^{\text {th }}$ October, Egypt. Sorghum (Sorghum bicolor [L.] Moench) Giza-15 and chickpea (Cicer arietinium) Giza-195 grains were obtained from Field Crops Research Institute, Agricultural Research Center, Giza, Egypt, during 2013 season.

All other ingredients sucrose, salt, baking powder, shortening, vanilla and cake improver (ECAP Company) were obtained from the local market, Cairo, Egypt.

\section{Preparations of sorghum and chickpea flour}

Sorghum grain and Chickpea were cleaned and milled in Food Technology Research Institute of Agriculture Research Center by using a laboratory disc mill to pass through a 60-mesh sieve as recommended by Hallab et al (1974). The resultant flour was referred as white sorghum or chickpea flour, and the coarse fraction was ground again in a laboratory mill. The flour from the second milling was blended with the white flour in order to obtain the whole sorghum or chickpea flour. The flours was packed in polyethylene bags and stored at $\left(-18^{\circ} \mathrm{C}\right)$ until analysis.

\section{Preparation of composite wheat flour}

Wheat flour was partially substituted by 10 and $15 \%$ of either sorghum flour (SF) or chickpea flour (CF). The flour mixtures were individually blended, homogenized then packed in polyethylene bags which tightly closed and stored at $\left(-18^{\circ} \mathrm{C}\right)$ until analysis.

\section{Sponge cake processing}

Sponge cake was performed according to Bennion and Bamford (1997) with the following recipes, the first recipe (1) wheat flour $(72 \%$ extraction) $(120 \mathrm{~g})$, whole fresh egg $(150 \mathrm{~g})$, sucrose (100), baking powder $(5 \mathrm{~g})$ and Vanilla $(2 \mathrm{~g})$ while the recipe (2) is as the same as recipe (1) with adding cake improver (1g).

\section{Biscuit processing}

Biscuit was prepared according to Wade (1988) with the following recipe: wheat flour $(72 \%$ extraction) $(100 \mathrm{~g})$, butter $(33 \mathrm{~g})$, sucrose $(36 \mathrm{~g})$, baking powder $(3 \mathrm{~g})$, vanilla $(0.25 \mathrm{~g})$ and water (18g).

\section{Analytical methods}

\section{Chemical analysis}

Moisture content, crude protein ( $\mathrm{N} \times 5.7$ ), lipids, ash and crude fiber contents were determined according to A.O.A.C. (2005). Nitrogen free extract (NFE) was calculated by difference. 
Rheological properties of the various blends were determined by Brabender farinograph and extensograph instruments according to A.A.C.C. (2002).

\section{Physical characteristics of sponge cake}

The weight of sponge cake was determined after cooling for one hour. Sponge cake volume was measured by rape seed displacement method as described by A.A.C.C., (2002). Specific volume of sponge cake were calculated by dividing the volume $\left(\mathrm{cm}^{3}\right)$ by their weight.

\section{Physical characteristics of biscuit}

According to Sai-Manohar and Haridas-Rao (1997), the diameter (D) and thickness ( $T$ ) of six biscuits were measured in millimeter by placing them edge to edge and by stacking one above the other, respectively. To obtain the average, measurements were made by rearranging and restacking. Spread ratio was calculated by dividing diameter of the biscuits $(\mathrm{mm})$ by their thickness $(\mathrm{mm})$. The weight and volume of sex biscuits were determined after cooling. The volume was measured by rape displaced by six biscuits. Specific volume was calculated by dividing volume $\left(\mathrm{cm}^{3}\right)$ by biscuit weight $(\mathrm{g})$.

\section{Organoleptic evaluation}

\section{Sponge cake}

Sponge cakes were evaluated for color, flavor, texture, taste and overall acceptability. The characteristics were scored from 10 points for each according to Kim et al (2012).

\section{Biscuit}

Biscuit was evaluated for crust, taste, odor, general appearance and crunchiness. The characteristics were scored from 20 points for each according to A.A.C.C. (2002).

\section{Statistical analysis}

All obtained results were statistically analyzed by SPSS computer software (SPSS, 2000). The calculated occurred by analysis of variance ANOVA and significant differences among the various scores were established using Duncan's multiple test according to Waller and Duncan (1969).

\section{RESULTS AND DISCUSSION}

\section{Proximate chemical composition of samples}

Proximate chemical composition of wheat, whole sorghum or whole chickpea flours are presented in Table (1). Chickpea flour was significantly showed the highest protein, lipids, ash and crude fiber being $23.26 \%, 6.2 \%, 1.19 \%$ and $2.45 \%$, respectively. On the other side, wheat flour significantly contained the highest percent of carbohydrate (Nitrogen free extract), $88.49 \%$ followed by sorghum flour (83.94\%) and chickpea flour $(66.18 \%)$. These results are in agreement with Demir et al (2009), Mohamed et al (2011) and Abdelghafor et al (2013).

\section{Rheological properties of dough sample}

From results presented in Table (2), it could be observed that by increasing the substitution levels in the blends of sorghum or chickpea flour, the water absorption was increased as compared with control sample (wheat flour). The increase in water absorption is probably due to the increase in total protein content of the composite flours and high water absorption capacity of legume proteins (Hegazy and Faheid, 2006).

Moreover, the results indicated that, substitution with sorghum or chickpea flour resulted in lower dough stability time, the increasing portion of the sorghum or chickpea flour in wheat blends led to a progressive decrease in the dough stability. The low dough stability of the sorghum flour blends might be due to the higher fiber content which destroyed the gluten matrix. These results are in agreement with Abdelghafor et al (2013), they found that farinograph properties such as stability decreased as the amount of substituted sorghum increased. The decrement in the stability time indicates weakness of dough strength. This weakness of the dough may be due to using chickpea flour which reduced the wheat gluten content (dilution effect) in the blends which make the dough more weak strength (Singh et al 1991).

Table (3) represented the extensograph parameters of wheat flour dough and wheat flour substituted with sorghum or chickpea flour. It could be noticed that the resistance to extension of the dough showed a pronounced decrease as the amount of sorghum or chickpea flour increase. 
Table 1. Proximate chemical composition of wheat, sorghum and chickpea flours (\% on dry weight basis)

\begin{tabular}{|lcccccc|}
\hline \multicolumn{1}{|c}{ Flour samples } & $\begin{array}{c}\text { Moisture } \\
\text { content }\end{array}$ & $\begin{array}{c}\text { Crude } \\
\text { Protein }\end{array}$ & Lipids & Ash & $\begin{array}{c}\text { Crude } \\
\text { fiber }\end{array}$ & NFE \\
\hline Wheat flour (72\%extraction) & $13.25^{\mathrm{a}}$ & $9.58^{\mathrm{b}}$ & $0.72^{\mathrm{c}}$ & $0.48^{\mathrm{c}}$ & $0.73^{\mathrm{c}}$ & $88.49^{\mathrm{a}}$ \\
Whole sorghum flour & $11.21^{\mathrm{b}}$ & $9.75^{\mathrm{b}}$ & $3.00^{\mathrm{b}}$ & $1.34^{\mathrm{b}}$ & $1.97^{\mathrm{b}}$ & $83.94^{\mathrm{b}}$ \\
Whole chickpea flour & $9.33^{\mathrm{c}}$ & $23.26^{\mathrm{a}}$ & $6.2^{\mathrm{a}}$ & $1.91^{\mathrm{a}}$ & $2.45^{\mathrm{a}}$ & $66.18^{\mathrm{c}}$ \\
\hline
\end{tabular}

Mean followed by different letters in the same column are significantly different by Duncan's multiple test $(P<0.05)$. Nitrogen free extract (NFE): Calculated by difference.

Table 2. Farinograph parameters of dough substituted with whole sorghum or chickpea flour

\begin{tabular}{|lcccccc|}
\hline \multicolumn{1}{c}{ Flour samples } & \multicolumn{7}{c|}{ Farinograph Parameters } \\
\cline { 2 - 7 } & WA (\%) & $\begin{array}{c}\text { AT } \\
\text { (min) }\end{array}$ & $\begin{array}{c}\text { DT } \\
\text { (min) }\end{array}$ & $\begin{array}{c}\text { DS } \\
\text { (min) }\end{array}$ & $\begin{array}{c}\text { MTI } \\
\text { (B.U) }\end{array}$ & $\begin{array}{c}\text { DW } \\
\text { (B.U) }\end{array}$ \\
\hline Wheat flour (control sample) & 57.90 & 0.50 & 1.00 & 3.00 & 110 & 130 \\
90\%WF+10\%SF & 58.00 & 0.50 & 1.50 & 2.00 & 90 & 110 \\
85\%WF+15\%SF & 58.40 & 0.50 & 1.00 & 1.50 & 90 & 120 \\
90\%WF+10\%CF & 59.10 & 1.00 & 1.50 & 2.50 & 100 & 130 \\
$85 \% W F+15 \% C F$ & 61.40 & 1.00 & 1.00 & 2.00 & 70 & 80 \\
\hline
\end{tabular}

WF: wheat flour, SF: sorghum flour, CF: chickpea flour, WA: Water absorption, AT: Arrival time, DT: Development time, DS: Dough stability, MTI: Mixing tolerance index, DW: Dough weakening

Table 3. Extensograph parameters of dough behavior of wheat flour (72\% extraction rate) and different substitution levels with whole sorghum or chickpea flour

\begin{tabular}{|lccccc|}
\hline \multicolumn{1}{c}{ Flour samples } & \multicolumn{5}{c|}{ Extensograph Parameters } \\
\cline { 2 - 6 } & $\begin{array}{c}\mathbf{R} \\
(\mathbf{B . U})\end{array}$ & $\begin{array}{c}\mathbf{E} \\
(\mathbf{m m})\end{array}$ & $\mathbf{R} / \mathbf{E}$ & $\begin{array}{c}\text { EME } \\
(\mathbf{m m})\end{array}$ & $\begin{array}{c}\text { Energy } \\
\left.\mathbf{( c m}^{2}\right)\end{array}$ \\
\hline Wheat flour (control sample) & 240 & 150 & 1.60 & 135 & 40 \\
$90 \% W F+10 \% S F$ & 200 & 150 & 1.33 & 130 & 34 \\
$85 \% W F+15 \% S F$ & 160 & 130 & 1.23 & 115 & 26 \\
$90 \% W F+10 \% \mathrm{CF}$ & 230 & 165 & 1.39 & 130 & 43 \\
$85 \% W F+15 \% \mathrm{CF}$ & 205 & 150 & 1.37 & 125 & 35 \\
\hline
\end{tabular}

WF: wheat flour, SF: sorghum flour, CF: chickpea flour, R: Resistance to extension, E: Extensibility, R/E: Proportional number, EME: Extensibility at maximum elasticity. 
These results are in accordance with Hegazy and Faheid (2006) reported that the addition of chickpea flour ratios to the wheat flour caused a decrease in the resistance to extension of the dough. The resistance to extension of the dough decreased as the result of increasing their fiber content that destroyed the gluten matrix in the dough, regardless of their content of protein as compared to the control sample (Ismail, 2007). From Table (3), it could be also observed that the dough extensibility was decreased in the blend at ratio $15 \%$ of the sorghum flour. Moreover, the blend contained $10 \%$ chickpea flour had higher extensibility value $(165 \mathrm{~mm})$ than that $(150 \mathrm{~mm})$ found in control dough.

With regard to the dough energy, the data showed that adding sorghum flour resulted in a reduction in its value and this effect increased by increasing the addition level. While, the addition of chickpea flour to wheat flour at the ratio of $10 \%$ caused a little bit increase; where the dough energy value reached $\left(43 \mathrm{~cm}^{2}\right)$, and then decreased to $\left(35 \mathrm{~cm}^{2}\right)$.

Effect of composite flour on sponge cake quality

Chemical composition of sponge cake samples

Proximate chemical analysis of sponge cake prepared from different composite flour samples are presented in Table (4). It could be observed that, crude protein, lipids, ash and crude fiber contents of cake samples were increased as increasing the replacement level by sorghum or chickpea flour. These increments were significant in the case of addition of chickpea flour. While in case of sorghum flour the increase in crude protein values and lipids were insignificant.

Generally, it could be seen that cake prepared from the investigated sorghum flour had less pronounced improvement percentage in its chemical composition rather than found in case of chickpea cake samples (Table, 4).

\section{Physical measurements of fresh sponge cake samples}

The physical properties of the produced cakes as affected by addition of sorghum or chickpea flour are presented in Table (5). Results showed that, there were no significant differences $(P>0.05)$ between control and cake samples prepared with
10 and $15 \%$ sorghum or chickpea flour for weight. In cake sample with improver, replacement of wheat flour with 10 and $15 \%$ sorghum flour caused a significantly decrease in cake volume in compared to control sample. But, the replacement of wheat flour with $10 \%$ chickpea flour caused a significantly increase in cake volume whether with $\left(190 \mathrm{~cm}^{3}\right)$ or without $\left(187 \mathrm{~cm}^{3}\right)$ improver when compared with the control $\left(183 \mathrm{~cm}^{3}\right)$. This data confirm the results of rheological dough properties (Tables, 2, 3) and also are in agreement with Gomez et al (2008).

As expected, the values of specific volume recorded the similar trend as that of volume. The highest value of specific volume was recorded in cake produced with $10 \%$ chickpea flour.

\section{Sensory evaluation of sponge cake samples}

There were significant differences $(P<0.05)$ in color between the control cake sample and cake prepared by $15 \%$ sorghum flour (Table, 6 ), but no significant differences $(P>0.05)$ in color could be observed between the cake prepared by $10 \%$ sorghum or 10 and $15 \%$ chickpea flours compared to the control cake sample. For flavor and texture, there were no significant differences $(P>0.05)$ between control cake sample and cake produced with $10 \%$ sorghum or chickpea flour. Concerning the taste and overall acceptability, it could be observed that, there were no significant differences $(P>0.05)$ between the control cake sample and cake prepared with $10 \%$ chickpea flour.

Generally, it could be concluded that, the sponge cake produced by substitution with $10 \%$ chickpea flour gave cake more sensory acceptable rather than the cake produced by added 10 and $15 \%$ sorghum flours or $15 \%$ chickpea flour.

Finally, it could be concluded that, chickpea flour successfully replace wheat flour with 10 or $15 \%$ in produced sponge cake without any unfavorable change especially for the cake produced by added cake improve (Table, 6 ).

\section{Effect of composite flour on biscuit quality}

\section{Chemical composition of different biscuit sam- ples}

The chemical composition of biscuit prepared from wheat flour (72\% extraction) and its blends with 10 and $15 \%$ of either sorghum or chickpea flour is recorded in Table (7). It could be noticed 
Table 4. Proximate chemical composition of sponge cake prepared from composite flours (\% on dry weight basis)

\begin{tabular}{|lcccccc|}
\hline \multicolumn{1}{|c}{ Cake samples } & $\begin{array}{c}\text { Moisture } \\
\text { content }\end{array}$ & $\begin{array}{c}\text { Crude } \\
\text { Protein }\end{array}$ & Lipids & Ash & $\begin{array}{c}\text { Crude } \\
\text { fiber }\end{array}$ & NFE \\
\hline Control sample $(100 \% \mathrm{WF})$ & $26.82^{\mathrm{a}}$ & $13.52^{\mathrm{b}}$ & $3.66^{\mathrm{c}}$ & $0.84^{\mathrm{d}}$ & $1.52^{\mathrm{b}}$ & $80.46^{\mathrm{a}}$ \\
$90 \% \mathrm{WF}+10 \% \mathrm{SF}$ & $25.52^{\mathrm{b}}$ & $13.68^{\mathrm{b}}$ & $3.81^{\mathrm{c}}$ & $0.94^{\mathrm{c}}$ & $1.67^{\mathrm{ab}}$ & $79.90^{\mathrm{b}}$ \\
$85 \% \mathrm{WF}+15 \% \mathrm{SF}$ & $25.68^{\mathrm{b}}$ & $13.73^{\mathrm{b}}$ & $3.92^{\mathrm{c}}$ & $1.02^{\mathrm{b}}$ & $1.72^{\mathrm{a}}$ & $79.61^{\mathrm{b}}$ \\
$90 \% \mathrm{WF}+10 \% \mathrm{CF}$ & $26.30^{\mathrm{ab}}$ & $14.32^{\mathrm{a}}$ & $4.26^{\mathrm{b}}$ & $1.04^{\mathrm{b}}$ & $1.77^{\mathrm{a}}$ & $78.61^{\mathrm{c}}$ \\
$85 \% \mathrm{WF}+15 \% \mathrm{CF}$ & $26.24^{\mathrm{ab}}$ & $14.65^{\mathrm{a}}$ & $4.59^{\mathrm{a}}$ & $1.11^{\mathrm{a}}$ & $1.85^{\mathrm{a}}$ & $77.80^{\mathrm{d}}$ \\
\hline
\end{tabular}

Mean followed by different letters in the same column are significantly different by Duncan's multiple test $(P<0.05)$. WF: wheat flour, SF: sorghum flour, CF: chickpea flour, NEF: Nitrogen free extract.

Table 5. Physical measurements of sponge cake prepared with wheat flour ( $72 \%$ extraction) and chickpea or sorghum flour

\begin{tabular}{|c|c|c|c|c|c|c|}
\hline \multirow{3}{*}{ Cake Samples } & \multicolumn{2}{|c|}{ Weight (g) } & \multicolumn{2}{|c|}{ Volume $\left(\mathrm{cm}^{3}\right)$} & \multicolumn{2}{|c|}{$\begin{array}{c}\text { Specific volume } \\
\left(\mathrm{cm}^{3} / \mathrm{g}\right)\end{array}$} \\
\hline & \multicolumn{6}{|c|}{ Recipes } \\
\hline & 1 & 2 & 1 & 2 & 1 & 2 \\
\hline Control sample & $47.50^{\mathrm{a}}$ & $48.00^{a}$ & $183^{b}$ & $190^{\mathrm{a}}$ & $3.85^{\mathrm{ab}}$ & $3.96^{a b}$ \\
\hline $90 \% W F+10 \% S F$ & $47.90^{\mathrm{a}}$ & $48.23^{a}$ & $182^{b}$ & $185^{\mathrm{b}}$ & $3.80^{\mathrm{b}}$ & $3.84^{b}$ \\
\hline $85 \% W F+15 \%$ SF & $47.00^{a}$ & $48.20^{a}$ & $180^{\mathrm{b}}$ & $185^{\mathrm{b}}$ & $3.83^{\mathrm{ab}}$ & $3.84^{b}$ \\
\hline $90 \% W F+10 \%$ CF & $46.75^{\mathrm{a}}$ & $47.55^{a}$ & $187^{a}$ & $190^{\mathrm{a}}$ & $4.00^{\mathrm{a}}$ & $4.00^{a}$ \\
\hline $85 \% W F+15 \%$ CF & $47.50^{a}$ & $48.17^{a}$ & $182.5^{\mathrm{b}}$ & $187^{a b}$ & $3.84^{\mathrm{ab}}$ & $3.88^{a b}$ \\
\hline
\end{tabular}

*Mean followed by different letters in the same column are significantly different by Duncan's multiple test $(P<0.05)$. WF: wheat flour, SF: sorghum flour, CF: chickpea flour

Recipe 1: sponge cake without improver, Recipe 2: sponge cake with improver.

Table 6. Sensory characteristics of sponge cake prepared with wheat flour and sorghum or chickpea flour

\begin{tabular}{|c|c|c|c|c|c|c|c|c|c|c|}
\hline \multirow[t]{3}{*}{ Cake samples } & \multicolumn{2}{|c|}{$\begin{array}{l}\text { Color } \\
(10)\end{array}$} & \multicolumn{2}{|c|}{$\begin{array}{c}\text { Flavor } \\
\text { (10) }\end{array}$} & \multicolumn{2}{|c|}{$\begin{array}{l}\text { Texture } \\
\text { (10) }\end{array}$} & \multicolumn{2}{|c|}{$\begin{array}{c}\text { Taste } \\
(10)\end{array}$} & \multicolumn{2}{|c|}{$\begin{array}{c}\text { Overall } \\
\text { acceptability } \\
(10)\end{array}$} \\
\hline & \multicolumn{10}{|c|}{ Recipes } \\
\hline & 1 & 2 & 1 & 2 & 1 & 2 & 1 & 2 & 1 & 2 \\
\hline $\begin{array}{l}\text { Control sample } \\
(100 \% \text { WF) }\end{array}$ & $9.70^{a}$ & $9.84^{a}$ & $9.50^{\mathrm{a}}$ & $9.68^{a}$ & $9.63^{a}$ & $9.50^{\mathrm{a}}$ & $9.82^{\mathrm{a}}$ & $9.74^{\mathrm{a}}$ & $9.70^{\mathrm{a}}$ & $9.80^{\mathrm{a}}$ \\
\hline $90 \% W F+10 \%$ SF & $9.42^{\mathrm{a}}$ & $9.42^{a}$ & $9.00^{\mathrm{ab}}$ & $9.24^{\mathrm{ab}}$ & $9.34^{a}$ & $9.22^{\mathrm{ab}}$ & $9.00^{b}$ & $9.33^{a}$ & $9.11^{\mathrm{ab}}$ & $9.50^{\mathrm{a}}$ \\
\hline $85 \% W F+15 \%$ SF & $8.62^{b}$ & $9.00^{b}$ & $8.22^{c}$ & $8.64^{c}$ & $8.74^{c}$ & $8.65^{\mathrm{c}}$ & $8.24^{c}$ & $8.70^{b}$ & $8.00^{d}$ & $8.50^{\mathrm{c}}$ \\
\hline $90 \% W F+10 \%$ CF & $9.55^{a}$ & $9.62^{a}$ & $9.32^{\mathrm{a}}$ & $9.51^{\mathrm{a}}$ & $9.53^{a}$ & $9.36^{a}$ & $9.20^{\mathrm{ab}}$ & $9.50^{\mathrm{a}}$ & $9.41^{a}$ & $9.64^{a}$ \\
\hline $85 \% W F+15 \%$ CF & $9.33^{a}$ & $9.34^{a}$ & $8.52^{b c}$ & $9.00^{\mathrm{b}}$ & $9.00^{b}$ & $9.16^{\mathrm{ab}}$ & $8.50^{\mathrm{bc}}$ & $9.11^{\mathrm{ab}}$ & $8.78^{b}$ & $9.34^{a}$ \\
\hline
\end{tabular}

*Mean followed by different letters in the same column are significantly different by Duncan's multiple test $(P<0.05)$. WF: wheat flour, SF: sorghum flour, CF: chickpea flour

Recipe 1: sponge cake without improver, Recipe 2: sponge cake with improver. 
Table 7. Proximate chemical composition (\%on dry weight basis) of biscuits prepared from wheat flour and replacement with sorghum or chickpea flour

\begin{tabular}{|lcccccc|}
\hline \multicolumn{1}{|c}{ Biscuit samples } & $\begin{array}{c}\text { Moisture } \\
\text { content }\end{array}$ & $\begin{array}{c}\text { Crude } \\
\text { Protein }\end{array}$ & Lipids & Ash & $\begin{array}{c}\text { Crude } \\
\text { fiber }\end{array}$ & NFE \\
\hline Control sample $(100 \% \mathrm{WF})$ & $3.84^{\mathrm{b}}$ & $9.62^{\mathrm{c}}$ & $18.68^{\mathrm{a}}$ & $0.55^{\mathrm{d}}$ & $0.82^{\mathrm{c}}$ & $70.33^{\mathrm{a}}$ \\
$90 \% \mathrm{WF}+10 \% \mathrm{SF}$ & $3.80^{\mathrm{b}}$ & $9.68^{\mathrm{c}}$ & $18.88^{\mathrm{a}}$ & $0.68^{\mathrm{c}}$ & $1.00^{\mathrm{b}}$ & $69.76^{\mathrm{ab}}$ \\
$85 \% \mathrm{WF}+15 \% \mathrm{SF}$ & $3.82^{\mathrm{b}}$ & $9.70^{\mathrm{c}}$ & $19.03^{\mathrm{a}}$ & $0.75^{\mathrm{b}}$ & $1.12^{\mathrm{ab}}$ & $69.40^{\mathrm{ab}}$ \\
$90 \% \mathrm{WF}+10 \% \mathrm{CF}$ & $3.90^{\mathrm{b}}$ & $10.30^{\mathrm{b}}$ & $19.42^{\mathrm{a}}$ & $0.75^{\mathrm{b}}$ & $1.10^{\mathrm{ab}}$ & $68.43^{\mathrm{b}}$ \\
$85 \% \mathrm{WF}+15 \% \mathrm{CF}$ & $4.20^{\mathrm{a}}$ & $11.42^{\mathrm{a}}$ & $19.50^{\mathrm{a}}$ & $0.83^{\mathrm{a}}$ & $1.18^{\mathrm{a}}$ & $67.07^{\mathrm{c}}$ \\
\hline
\end{tabular}

Mean followed by different letters in the same column are significantly different by Duncan's multiple test $(P<0.05)$. WF: wheat flour, SF: sorghum flour, CF: chickpea flour, NEF: Nitrogen free extract.

that crude protein, lipids, ash and crude fiber contents were increased in all biscuit samples with increasing of either the sorghum or chickpea flour levels from 10 and 15\%. The increments were significant when CF was added. These results are in agreement with those reported by Shahzadi et al (2005) and Yadav et al (2012).

\section{Physical measurements of biscuit samples}

It could be observed at Table (8) that, the control sample had a weight of $81.5 \mathrm{~g}$ and volume 240 $\mathrm{cm}^{3}$ with specific volume $2.94 \mathrm{~cm}^{3} / \mathrm{g}$. On the other side, replacement of wheat flour with 10 and $15 \%$ sorghum flour caused gradually decrease in volume and specific volume of biscuit. On the other hand, there were no significant differences $(P>0.05)$ in volume and specific volume of biscuit between the control sample and biscuit sample with $10 \%$ chickpea flour. Also, the width values for biscuits with chickpea flour were higher than those for biscuit with the sorghum flour at the same substitution level. There were no significant differences $(P>0.05)$ between the thickness and spread ratio of wheat flour biscuit (control) compared to that of sorghum or chickpea- wheat composite flour biscuit. On the other hand, the spread ratio of biscuit with the sorghum or chickpea flour at levels $15 \%$ was found to be a higher than that found with $10 \%$ sorghum or chickpea flour.

There were no significant differences $(P>0.05)$ between the weight, thickness and spread ratio of $100 \%$ wheat flour biscuit (control) compared to that of sorghum-wheat composite flour biscuit (Abdelowale et al 2012). Also, Saleh et al (2012) found that, the average width value of the control biscuit made from wheat flour was $6.1 \mathrm{~cm}$, whereas the corresponding values of biscuit supplemented with the chickpea flour ranged between 6.0 and $6.3 \mathrm{~cm}$ at substitution levels of 5 to $15 \%$.

\section{Sensory evaluation of biscuit samples}

Results in Table (9) noticed that, increasing the level of the sorghum flour in the wheat flour formulation used in biscuit making, the sensory scores for color, taste, odor, appearance and crunchiness of biscuit decreased. Replacement of wheat flour with $15 \%$ chickpea flour was not significantly $(P>0.05)$ affected which nearly observed the same score of control samples.

Biscuit made from blends containing 15\% level of chickpea flour had maximum color acceptability. In addition, there were no significant differences $(P>0.05)$ between control biscuit sample and biscuit contained $10 \%$ level of sorghum flour for taste. The control sample and biscuit containing 10 and $15 \%$ chickpea flour had higher total scores, whereas biscuit containing $15 \%$ sorghum flour were found to be unacceptable to panelists.

The obtained results are in agreement with Elkhalifa and El-Tinay (2002); Essia et al (2007) and Mirdula et al (2007). Saleh et al (2012) found that, no significant differences $(P>0.05)$ were noticed at level of $5 \%$ defatted soybean flour and $10 \%$ chickpea flour when compared with the control.

Generally, it could be concluded that, replacement of wheat flour with chickpea flour gave biscuit more sensory acceptable rather than of sorghum flour. 
Table 8. Physical measurements of biscuit prepared with wheat flour (72\% extraction) and replacement with chickpea or sorghum flour

\begin{tabular}{|lccccccc|}
\hline Biscuit samples & $\begin{array}{c}\text { Weight } \\
(\mathbf{g})\end{array}$ & $\begin{array}{c}\text { Volume } \\
\left(\mathbf{c m}^{3}\right)\end{array}$ & $\begin{array}{c}\text { Sp.v. } \\
\left(\mathbf{c m}^{3} / \mathbf{g}\right)\end{array}$ & $\begin{array}{c}\text { Reduction } \\
\text { in Sp.v. } \\
(\%)\end{array}$ & $\begin{array}{c}\text { Width } \\
(\mathbf{W}) \\
(\mathbf{m m})\end{array}$ & $\begin{array}{c}\text { Thickness } \\
(\mathbf{T}) \\
(\mathbf{m m})\end{array}$ & $\begin{array}{c}\text { Spread } \\
\text { ratio } \\
\text { W/T }\end{array}$ \\
\hline $\begin{array}{l}\text { Control sample } \\
(100 \% \mathrm{WF})\end{array}$ & $81.58^{\mathrm{ab}}$ & $240^{\mathrm{a}}$ & $2.94^{\mathrm{a}}$ & $0^{\mathrm{c}}$ & $56.3^{\mathrm{ab}}$ & $9.2^{\mathrm{a}}$ & $6.12^{\mathrm{a}}$ \\
$90 \% \mathrm{WF}+10 \% \mathrm{SF}$ & $81.82^{\mathrm{ab}}$ & $220^{\mathrm{b}}$ & $2.69^{\mathrm{b}}$ & $8.50^{\mathrm{b}}$ & $54.6^{\mathrm{bc}}$ & $9.0^{\mathrm{a}}$ & $6.07^{\mathrm{a}}$ \\
$85 \% \mathrm{WF}+15 \% \mathrm{SF}$ & $82.11^{\mathrm{ab}}$ & $200^{\mathrm{c}}$ & $2.44^{\mathrm{c}}$ & $17.01^{\mathrm{a}}$ & $53.4^{\mathrm{c}}$ & $8.7^{\mathrm{a}}$ & $6.14^{\mathrm{a}}$ \\
$90 \% \mathrm{WF}+10 \% \mathrm{CF}$ & $80.52^{\mathrm{b}}$ & $236^{\mathrm{a}}$ & $2.93^{\mathrm{a}}$ & $0.34^{\mathrm{c}}$ & $55.2^{\mathrm{bc}}$ & $9.1^{\mathrm{a}}$ & $6.07^{\mathrm{a}}$ \\
$85 \% \mathrm{WF}+15 \% \mathrm{CF}$ & $83.24^{\mathrm{a}}$ & $225^{\mathrm{b}}$ & $2.70^{\mathrm{b}}$ & $8.16^{\mathrm{b}}$ & $57.0^{\mathrm{a}}$ & $9.0^{\mathrm{a}}$ & $6.33^{\mathrm{a}}$ \\
\hline
\end{tabular}

Mean followed by different letters in the same column are significantly different by Duncan's multiple test $(P<0.05)$. WF: wheat flour, SF: sorghum flour, CF: chickpea flour, Sp.v.: Specific volume

Table 9. Sensory characteristics of biscuit prepared by replacement of wheat flour (72\% extraction) with sorghum or chickpea flour

\begin{tabular}{|lccccccc|}
\hline Biscuit samples & Color & Taste & odor & appearance & crunchiness & $\begin{array}{c}\text { Total } \\
\text { scores }\end{array}$ & acceptance \\
\hline $\begin{array}{l}\text { Control sample } \\
(100 \% \mathrm{WF})\end{array}$ & $18.3^{\mathrm{b}}$ & $19.7^{\mathrm{a}}$ & $19.9^{\mathrm{a}}$ & $18.5^{\mathrm{b}}$ & $19.6^{\mathrm{a}}$ & $96.0^{\mathrm{a}}$ & $\mathrm{V}$ \\
$90 \% \mathrm{WF}+10 \% \mathrm{SF}$ & $16.5^{\mathrm{c}}$ & $19.4^{\mathrm{a}}$ & $19.0^{\mathrm{b}}$ & $17.5^{\mathrm{c}}$ & $18.3^{\mathrm{b}}$ & $90.7^{\mathrm{c}}$ & $\mathrm{V}$ \\
$85 \% \mathrm{WF}+15 \% \mathrm{SF}$ & $18.7^{\mathrm{b}}$ & $17.7^{\mathrm{c}}$ & $18.7^{\mathrm{b}}$ & $16.5^{\mathrm{d}}$ & $17.4^{\mathrm{c}}$ & $89.0^{\mathrm{d}}$ & $\mathrm{G}$ \\
$90 \% \mathrm{WF}+10 \% \mathrm{CF}$ & $18.7^{\mathrm{b}}$ & $18.3^{\mathrm{b}}$ & $18.7^{\mathrm{b}}$ & $18.7^{\mathrm{b}}$ & $19.5^{\mathrm{a}}$ & $93.0^{\mathrm{b}}$ & $\mathrm{V}$ \\
$85 \% \mathrm{WF}+15 \% \mathrm{CF}$ & $19.7^{\mathrm{a}}$ & $18.7^{\mathrm{b}}$ & $18.7^{\mathrm{b}}$ & $19.7^{\mathrm{a}}$ & $18.6^{\mathrm{b}}$ & $96.3^{\mathrm{a}}$ & $\mathrm{V}$ \\
\hline
\end{tabular}

Mean followed by different letters in the same column are significantly different by Duncan's multiple test $(P<0.05)$. WF: wheat flour, SF: sorghum flour, CF: chickpea flour

V: 90-100 Very Good, G: 80-89 Good, S: 70-79 Satisfactory, Q: Less Than 70 Questionable.

\section{REFERANCES}

A.A.C.C. 2002. Approved Method of American Association of Cereal Chemists. Approved Methods the A.A.C.C. published by the American Association of Cereal Chemists . 13 $3^{\text {th }}$ Ed., St. Paul, Minnesota, USA.

A.O.A.C. 2005. Official Methods of Analysis Association of Official Analytical Chemists. $18^{\text {th }}, 481$ North Frederick Avenue, Gaithersburg, Maryland 20877-2417, USA.

Abdelghafor, R.F., Mustafa, A.l., Ibrahim, A.M.H., Chen, Y.R. and Krishnan, P.G. 2013.
Effect of sorghum flour addition on chemical and rheological properties of hard white winter wheat. Advance J. Food Scie. and Technol.5 (11): 1407-1412.

Abdelowale, A.A., Adegoke, M.T., Sanni, S.A., Adegunwa, M.O. and Fetuga, G.O. 2012. Functional properties and biscuit making potentiale of sorghum-wheat flour composite. American J. Food Technol., 7(6): 372-379.

Barakat, A.E. 2003. Nutritional studies on some cereal products. Ph.D. Thesis, Food Sci and Technol. Dept., Fac. of Agric., Zagazig Univ. Egypt. 
Bennion, E.B. and Bamford, G.S.T. 1997. The Technology of Cake Making, $6^{\text {th }}$ ed. pp. 285288. Published by Blackie Academic and Professional, Chapman \& Hall, London, UK.

Chavan, J.K. and Kadam, S.S. 1993. Nutritional enrichment of bakery products by supplementation with non-wheat flours. CRC Crit. Rev. Food Sci. Nutr, 33: 189-226.

Demir, B., Bilgicli, N., Elgun, A. and Demir, M.K. 2009. The effect of partial substitution of wheat flour with chickpea flour on the technological, nutritional and sensory properties of couscous. J. Food Quality 33: 728 - 741.

Dewettinck, F., Van Bockstaele, B. and Van de Walle, J. 2008. Nutritional value of bread: Influence of processing, food interaction and consumer perception. J. Cereal Sci., 48: 243257.

Elkhalifa, A.O. and El-Tinay, A.H. 2002. Effect of cysteine on bakery products from wheatsorghum blends. Food Chem., 77: 133-137.

Essia, H.A., Hussein, A.S. and Mostafa, B.E. 2007. Rheological properties and quality evaluation of Egyptian balady bread and biscuits supplemented with flours of ungerminated and germinated legume seeds or mushroom. Pol. J. Food Nutr. Sci., 57(4): 487 - 490.

FAO, 2013. Food and Agriculture Organization of the United Nations. www.fao.org, (2013).

Finney, P.L. 1989. Soft wheat; View from the eastern United States. Cereal Foods World, 34: 682-687.

Ghattas, L.A., Hanna, L.M., Tapozada, S.T. and Shebini, S.M. 2008. some complementary hypoglycemic supplements from grain legumes for the management of type 2 diabetic mellitus. J. Med. Sci., 8: 102-110.

Gomez, M., Oliete, B., Rosell, C.M., Pando, V. and Fernandez, E. 2008. Studies on cake quality made of wheat - chickpea flour blends. LWT- Food Scie. and Technol. 41: 17011709.

Hallab, A.H., Khatchadorian, H.A. and Jabr, I. 1974. The nutritive value and organoleptic properties of white Arabic bread supplemented with soybean and chickpea. Cereal Chem. 51(5): 106-111.

Hegazy, N.A. and Faheid, S.M.A. 2006. Rheological and Sensory characteristics of dough and cookies based on wheat, soybean, chickpea and lupine flour. Molecular Nutrition and Food Research, 34(9): 835 -841.

Hernandez, M. and Sotelo, A. 1984. Nutritional evaluation of wheat flour cookies supplemented with chickpea, cheese, whey and amino acids. Nutrition Reports International; 29(4): 845858.

Hui, Y.H. 1992. Encyclopedia of Food Science and Technology. John Wiley and Sons. Inc., Canada, pp. 204- 210.

Hulse, J.P., Laing, E.M. and Pearson, O.E. 1980. Sorghum and Millet: their Composition and $\mathrm{Nu}-$ tritive value, pp. 404-997. Academic Press, London, UK.

Hussein, H.M., Hussein, M.M. and El-Damohery, S.T. 2006. The effect of natural formulated functional biscuits on edderly bone health. J. Medical Sci., 6: 937-943.

Ismail, M.M. 2007. Physical, chemical and biological studies on bread fortified by some legumes flour. M.Sc. Thesis, Food Tech. Dept., Faculty of Agriculture, El-Fayoum University, Egypt.

Iwegbue, C.M.A. 2012. Metal contents in some brands of biscuit consumed in southern Nigeria. Am. J. Food Technol., 7: 160-167.

Kim, J.H., Lee, H.J., Lee, H.S., Lim, E.J., Imm, J.Y. and Suh, H.J. 2012. Physical and sensory characteristics of fibre-enriched sponge cakes made with Opuntia humifusa. Food Science and Technology 47: 478-484.

Kure, O.A., Bahayo, E.J. and Daniel, E.A. 1998. Studies on the proximate composition and effect of flour particle size on acceptability of biscuit produced from blends of soya beans and plantain flour. Namida Tech-Scope J., 3: 1721.

Mirdula, D.; R.K. Gupta and M.R. Manikantan 2007. Effect of incorporation of sorghum flour to wheat flour on quality of biscuit fortified with defatted soy flour. Am. J. Food Tech. 2(5):428434.

Mohamed, N.A., Ahmed, I.A.M. and Babiker, E.E. 2011. Nutritional evaluation of sorghum flour (sorghum bicolor L. monech) during processing of Injera. World Academy of Science, Engineering and Technology, 51: 72-76.

Murty, D.S. and Renard, C. 2001. Sorghum. In crops in tropical Africa. Raemaekers, R.H. (ed.). pp. 68-96. Brussels, Belgium.

Sai-Manohar, R. and Haridas-Rao, P. 1997. Effect of sugars on the rheological characteristics of biscuit dough and quality of biscuit. J. Sci. Food Agric., 75: 383-390.

Saleh, A.M., Salama, A.E., Bedeir, S.H. and AbdElazim, E.I. 2012. Effect of partial substitution of wheat flour with either defatted soybean or chickpea flours at different ratios on rheological and physical properties of dough and quality 
characteristics of biscuit. J. Appl. Sci. Research, 8(12): 5806 - 5817.

Shahzadi, N., Masood, S., Saleem, U.R. and Kamram, S. 2005. Chemical characteristics of various composite flours. International $\mathbf{J}$. Agric. Biology, 7(1): 105-108.

Singh, N.K., Harinder, K.S. and Sekhon, B.K. 1991. Study on the improvement of functional and baking properties of wheat-chickpea flour blends. Department of Science and Technology. Punjab Agriculture University, Ludhiana, India.
SPSS, 2000. Statistical package for Social Sciences. SPSS for Widows, Version 19, SPSS Inc., Chicago, IL, USA.

Wade, P. 1988. Biscuit, cookies and crackers. Vol.1. Recipe of biscuit used during investigation, pp. 102-114. Applied Science Pulishers LTD, London, UK.

Waller, R.A. and Duncan, D.B. 1969. A Bayes Rule for the Symmetric Multiple Comparison Problem. J. American Statistical Association, 64: 1484 -1499.

Yadav, R.B., Yadav, B.S. and Dhull, N. 2012. Effect of incorporation of plantain and chickpea flours on the quality characteristics of biscuits. J. Food Sci. Technol., 49(2): 207-213. 